\begin{tabular}{|c|l|}
\hline Title & Variable temperature neutron diffraction studies of single cry stals of LiND2 \\
\hline Author(s) & $\begin{array}{l}\text { I sobe, Shigehito; Ohnuki, Somei; David, William I. F.; Gutmann, Matthias; Jones, Martin O.; Edwards, Peter P.; } \\
\text { Ichikawa, Takayuki; Kojima, Y oshitsugu }\end{array}$ \\
\hline Citation & $\begin{array}{l}\text { International Journal of Hydrogen Energy, 36(13), 7909-7913 } \\
\text { https://doi.org/10.1016/.ijhydene.2011.01.086 }\end{array}$ \\
\hline Issue Date & 2011-07 \\
\hline Doc URL & http://hdl.handle.net/2115/46793 \\
\hline Type & article (author version) \\
\hline File Information & IJHE36-13_7909-7913.pdf \\
\hline
\end{tabular}

Instructions for use 


\title{
Variable Temperature Neutron Diffraction Studies of Single Crystals of LiND 2
}

\author{
Shigehito Isobe, Somei Ohnuki \\ Graduate School of Engineering, Hokkaido University \\ $\mathrm{N}-13, \mathrm{~W}-8$ \\ Sapporo 0608628, Japan \\ William I. F. David, Matthias Gutmann \\ ISIS Facility, Rutherford Appleton Laboratory \\ Chilton, Didcot \\ Oxon OX11 0QX, U.K. \\ Martin O. Jones, Peter P. Edwards \\ Inorganic Chemistry Laboratory, University of Oxford \\ South Parks Road \\ Oxford OX1 3QR, U.K. \\ Takayuki Ichikawa, Yoshitsugu Kojima \\ Institute for Advanced Materials Research, Hiroshima University \\ 1-3-1 Kagamiyama \\ Higashi Hiroshima 739-8530, Japan
}

\begin{abstract}
We have synthesized a single crystal of lithium amide $\left(\mathrm{LiNH}_{2}, \mathrm{LiND}_{2}\right)$ by melting method, and performed neutron diffraction of the single crystal at variable temperature. $\mathrm{LiND}_{2}$ is tetragonal structure and I-4 space group. Lattice parameters and unit cell volume of $\mathrm{LiND}_{2}$ at room temperature, $50{ }^{\circ} \mathrm{C}, 100{ }^{\circ} \mathrm{C}, 150{ }^{\circ} \mathrm{C}$ and $200{ }^{\circ} \mathrm{C}$ were determined. Both of the lattice parameters and the unit cell volume increase with increase of temperature. From these results, we have estimated coefficient of volumetric thermal expansion $\alpha_{\mathrm{V}}$ of $\mathrm{LiND}_{2}$ to be $222 * 10^{-6} / \mathrm{K}$. With increase of temperature, all thermal ellipsoids gradually expand because of thermal vibration.
\end{abstract}

Key words: hydrogen storage, lithium amide, single crystal, neutron diffraction

\section{INTRODUCTION}

It is necessary to establish high-performance hydrogen storage ( $\mathrm{H}$-storage) technologies, for utilizing hydrogen as one of the secondary energies. Three $\mathrm{H}$-storage containers of liquid hydrogen, high-pressure gas hydrogen and absorbed hydrogen in $\mathrm{H}$-storage materials are considered for future practical use as $\mathrm{H}$-storage tanks. Among them, $\mathrm{H}$-storage materials can more densely store hydrogen than high-pressure gas or liquid hydrogen $[1,2]$. Therefore, the tank system using the Hstorage materials has been considered as the most suitable one for $\mathrm{H}$-storage. As one of the most promising $\mathrm{H}$-storage materials, variable amide-imide of light metal such as $\mathrm{Li}, \mathrm{Na}, \mathrm{Mg}$ and $\mathrm{Ca}$ has been studied [3-16]. Among them, $\mathrm{Li}-\mathrm{N}-\mathrm{H}$ system was firstly reported by Chen et al. [3]. Lithium nitrides can absorb and desorb a large amount of hydrogen in the two consecutive reactions as follows:

$\mathrm{Li}_{3} \mathrm{~N}+\mathrm{H}_{2} \leftrightarrow \mathrm{Li}_{2} \mathrm{NH}+\mathrm{LiH}(1)$ 
$\mathrm{Li}_{2} \mathrm{NH}+\mathrm{H}_{2} \leftrightarrow \mathrm{LiNH}_{2}+\mathrm{LiH}(2)$

So far a lot of research on this system has been reported, such reaction mechanism [5-9], catalytic effect of titanium compound on the dehydrogenating property [10,11], and thermodynamic property of $\mathrm{Li}-\mathrm{N}-\mathrm{H}$ [12]. In this work, we have synthesized single crystal of lithium amide, and then we have performed thermal analyses and neutron diffraction of the single crystal at variable temperature.

\section{EXPERIMENTAL}

Single crystal of $\mathrm{LiND}_{2}$ was prepared by heat-treatment of $\mathrm{LiND}_{2}$ powder. Firstly, we prepared the powder of $\mathrm{LiND}_{2}$ by ball-milling of $\mathrm{LiD}$ under $0.5 \mathrm{MPa} \mathrm{ND}_{3}$ gas in same method as synthesizing $\mathrm{LiNH}_{2}$ [17]. $\mathrm{LiD}\left(98\right.$ atom\% D) and $\mathrm{ND}_{3}(99$ atom\% D) gas were purchased from Aldrich and ISOTEC, respectively. The powder $\mathrm{LiND}_{2}$ was put into high-pressure cell made of SUS, and 0.5 MPa ND 3 gas was introduced at room temperature. Here, $\mathrm{ND}_{3}$ gas can avoid $\mathrm{LiND}_{2}$ decomposing to $\mathrm{Li}_{2} \mathrm{ND}$ during the heat-treatment. The heat-treatment of the $\mathrm{LiND}_{2}$ powder was programmed as follows,

Step 1: Heating from $20^{\circ} \mathrm{C}$ to $400{ }^{\circ} \mathrm{C}$ for $2 \mathrm{hrs}$,

Step 2: Plateau at $400{ }^{\circ} \mathrm{C}$ for $40 \mathrm{hrs}$,

Step 3: Cooling down from $400{ }^{\circ} \mathrm{C}$ to $380{ }^{\circ} \mathrm{C}$ for $60 \mathrm{hrs}$,

Step 4: Plateau at $380^{\circ} \mathrm{C}$ for $60 \mathrm{hrs}$,

Step 5: Cooling down from $380{ }^{\circ} \mathrm{C}$ to $360{ }^{\circ} \mathrm{C}$ for $60 \mathrm{hrs}$,

Step 6: Cooling down from $360^{\circ} \mathrm{C}$ to $260{ }^{\circ} \mathrm{C}$ for $20 \mathrm{hrs}$,

Step 7: Cooling down from $260^{\circ} \mathrm{C}$ to $20^{\circ} \mathrm{C}$ for $10 \mathrm{hrs}$.

The melting point of $\operatorname{LiND}_{2}$ is $380{ }^{\circ} \mathrm{C}$, therefore solid $\mathrm{LiND}_{2}$ should be completely melted at Step 2 , and then we slowly cool liquid $\mathrm{LiND}_{2}$ for crystal growth. After the heat-treatment, we obtained several granules of $\mathrm{LiND}_{2}$, which are approximately $2 * 2 * 2 \mathrm{~mm}^{3}$ of size and transparent, as shown in Figure 1.

Scanning Electron Microscope (SEM) measurement was performed on JEOL JSM-6380. Thermal properties of the single crystal $\mathrm{LiNH}_{2}$ were simultaneously examined by thermogravimetry (TG), differential thermal analysis (DTA), and thermal desorption mass spectroscopy (TDMS) from room temperature to $450{ }^{\circ} \mathrm{C}$ with $2{ }^{\circ} \mathrm{C} /$ min heating rate. The TG-DTA equipment (Rigaku, TG8120) connected to the TDMS apparatus (Anelva, M-QA200TS) is installed into the glove-box (Miwa MFG Co. Ltd., MP-P60W) filled with purified argon. All treatments are operated without exposing the samples to air for avoiding unexpected reactions with oxygen or moisture.

We performed neutron diffraction measurement at variable temperature of the single crystals on SXD (the Single Crystal Diffractometer) in ISIS [18]. Structural refinements were completed using the GSAS/EXPGUI software package [19].

\section{RESULTS AND DISCUSSIONS}

The results of TG, DTA and TDMS of the single crystal $\mathrm{LiNH}_{2}$, which was prepared by same method as single crystal $\mathrm{LiND}_{2}$, are shown in Figure 2. Sharp peaks, corresponding to $\mathrm{NH}_{3}$ desorption and endothermic reaction, appear at $374{ }^{\circ} \mathrm{C}$ in both profiles of TDMS and DTA, respectively. These peaks should originate with a decomposition from $\mathrm{LiNH}_{2}$ to $\mathrm{Li}_{2} \mathrm{NH}\left(2 \mathrm{LiNH}_{2} \rightarrow\right.$ $\left.\mathrm{Li}_{2} \mathrm{NH}+\mathrm{NH}_{3}\right)$ and melting of $\mathrm{LiNH}_{2}$ itself [7]. Certainly, the weight loss $\left(-40 \mathrm{wt} \% \%\right.$ at $\left.450{ }^{\circ} \mathrm{C}\right)$ of $\mathrm{NH}_{3}$ desorption by TG agrees with the expected amount from the decomposition. In the case that 
we performed DTA and TDMS for powder of $\mathrm{LiNH}_{2}$ as purchased, which was not single crystal, much broader peaks are shown in those profiles [7].

$\mathrm{LiND}_{2}$ has a tetragonal structure.at room temperature, $50{ }^{\circ} \mathrm{C}, 100{ }^{\circ} \mathrm{C}, 150{ }^{\circ} \mathrm{C}$ and $200{ }^{\circ} \mathrm{C}$ are reported in Table 1

The lattice parameters at room temperature are in agreement with those reported in the literature [20]. Both of the lattice parameters and the unit cell volume increase with increase of temperature, as shown in Figure 2 and 3. From these results, we estimate coefficient of volumetric thermal expansion $\alpha_{V}$ of $\mathrm{LiND}_{2} . \alpha_{V}$ is defined as,

$$
\alpha_{V}=\frac{1}{V} \frac{\Delta V}{\Delta T}
$$

The estimated value is $222 * 10^{-6} / \mathrm{K}$. (The standard deviation is $\pm 1.4^{*} 10^{-6} / \mathrm{K}$.) Schematic structures with thermal ellipsoids of $\mathrm{LiND}_{2}$ determined by neutron diffraction at room temperature, $50{ }^{\circ} \mathrm{C}$, $100{ }^{\circ} \mathrm{C}$ and $150{ }^{\circ} \mathrm{C}$ are shown in Figure 4. The refinements were carried out using GSAS program. With increase of temperature, all thermal ellipsoids gradually expand because of thermal vibration.

\section{CONCLUSIONS}

We have succeeded to synthesize the single crystal of $\mathrm{LiND}_{2}$ by the melting method. The melting point of single crystal of $\mathrm{LiND}_{2}$ is $374{ }^{\circ} \mathrm{C}$ with decomposition from $\mathrm{LiND}_{2}$ to $\mathrm{Li}_{2} \mathrm{ND}$ and $\mathrm{ND}_{3}$. By the results of neutron diffraction on the single crystal at variable temperature, coefficient of volumetric thermal expansion $\alpha_{V}$ of $\mathrm{LiND}_{2}$ is estimated to be $222 * 10^{-6} / \mathrm{K}$. Schematic structures with thermal ellipsoids of $\mathrm{LiND}_{2}$ determined by neutron diffraction show that all thermal ellipsoids gradually expand because of thermal vibration with increase of temperature. For designing the tank of hydrogen storage materials in Fuel Cell Vehicle, it is important for to consider the volumetric thermal coefficient of hydrogen storage materials.

\section{ACKNOWLEDGMENTS}

The authors gratefully acknowledge Dr. Marco Sommariva, Dr. Hino and Dr. Paik for their help. This work has been partially supported by NEDO under "Advanced Fundamental Research Project on Hydrogen Storage Materials".

\section{REFERENCES}

[1]. Schlapbach L, Züttel A, Hydrogen-storage materials for mobile applications. Nature 2001;414: $353-8$.

[2]. Grochala W, Edwards PP. Thermal Decomposition of the Non-Interstitial Hydrides for the Storage and Production of Hydrogen. Chem. Rev. 2004;104: 1283-315.

[3]. Chen P, Xiong ZT, Luo JZ, Lin JY, Tan KL. Interaction of hydrogen with metal nitrides and imides. Nature 2002;420: 302-4.

[4]. Pinkerton FE. Decomposition kinetics of lithium amide for hydrogen storage materials. J. Alloys Compd. 2005;400: 76-82.

[5]. Hu YH, Ruckenstein E. Ultrafast Reaction between $\mathrm{LiH}$ and $\mathrm{NH} 3$ during $\mathrm{H} 2$ Storage in $\mathrm{Li}_{3} \mathrm{~N} \mathrm{~J}$. Phys. Chem. A 2003;107: 9737-39.

[6]. Chen P, Xiong ZT, Luo JZ, Lin JY, Tan KL. Interaction between Lithium Amide and Lithium Hydride. J. Phys. Chem. B 2003, 107, 10967-70. 
[7]. Ichikawa T, Hanada N, Isobe S, Leng HY, Fujii H. Mechanism of novel reaction from $\mathrm{LiNH}_{2}$ and $\mathrm{LiH}$ to $\mathrm{Li}_{2} \mathrm{NH}$ and $\mathrm{H}_{2}$ as a promising hydrogen storage system. J Phys Chem B 2004;108: 7887-92.

[8]. Isobe S, Ichikawa T, Hino S, Fujii H. Hydrogen desorption mechanism in a Li-N-H system by means of the isotopic exchange technique. J Phys Chem B 2005;109: 14855-8.

[9]. David WIF, Jones MO, Gregory DH, Jewell CM, Johnson SR, Walton AP, Edwards PP. A Mechanism for Non-stoichiometry in the Lithium Amide/ Lithium Imide Hydrogen Storage Reaction. J. Am. Chem. Soc. 2007;129: 1594-601.

[10]. Isobe S, Ichikawa T, Hanada N, Leng HY, Fichtner M, Fuhr O, Fujii H. Effect of Ti catalyst with different chemical form on $\mathrm{Li}-\mathrm{N}-\mathrm{H}$ hydrogen storage properties. J. Alloys Compd. 2005;404: 439-42.

[11]. Isobe S, Ichikawa T, Kojima Y, Fujii H. Characterization of titanium based catalysts in the Li-N-H hydrogen storage system by X-ray absorption spectroscopy. J. Alloys Compd. 2007;446-447: 360-2

[12]. Isobe S, Ichikawa T, Tokoyoda K, Hanada N, Leng HY, Fujii H, Kojima Y. Evaluation of enthalpy change due to hydrogen desorption for lithium amide/imide system by differential scanning calorimetry. Thermochimica Acta 2008;468 : 35-8.

[13]. Leng HY, Ichikawa T, Hino S, Hanada N, Isobe S, Fujii H. New Metal-N-H System Composed of $\mathrm{Mg}\left(\mathrm{NH}_{2}\right)_{2}$ and $\mathrm{LiH}$ for Hydrogen Storage. J. Phys. Chem. B 2004;108: 8763-5.

[14]. Lowton RL, Jones MO, David WIF, Johnson SR, Sommariva M, Edwards PP. The synthesis and structural investigation of mixed lithium/sodium amides. J. Mater. Chem. 2008; 18: 2355-60

[15]. Xiong Z, Wu G, Hu J, Chen P. Ternary Imides for Hydrogen Storage. Adv. Mater. 2004;16: $1522-5$.

[16]. Hino S, Ichikawa T, Leng HY, Fujii H. Hydrogen desorption properties of the $\mathrm{Ca}-\mathrm{N}-\mathrm{H}$ system. J. Alloys Compd. 2005;398: 62-6.

[17]. Leng HY, Ichikawa T, Hino S, Hanada N, Isobe S, Fujii H. Synthesis and decomposition reactions of metal amides in metal-N-H hydrogen storage system. J. Power Sources 2006;156: $166-70$.

[18]. http://www.isis.rl.ac.uk/Crystallography/SXD/

[19]. Toby BH. EXPGUI, a graphical user interface for GSAS. J. Appl. Crystallogr. 2001;34: $210-3$.

[20]. Jacob HV, Juza R. Neubestimmung der Kristallstruktur des Lithiumamids. Z. Anorg. Allg. Chem. 1972;391: 271-9.

\section{Figure captions}

Figure 1

Picture and SEM image of single crystal $\mathrm{LiNH}_{2}$, which was synthesized from $\mathrm{LiH}$ and $\mathrm{NH}_{3}$ by same method as $\mathrm{LiND}_{2}$

Figure 2

Thermal properties (TG, DTA and TDMS with $2{ }^{\circ} \mathrm{C} / \mathrm{min}$ heating rate) of single crystal $\mathrm{LiNH}_{2}$, which was synthesized from $\mathrm{LiH}$ and $\mathrm{NH}_{3}$ by same method as $\mathrm{LiND}_{2}$

Figure 3

Plot of lattice parameters "a, b" and "c" at room temperature, $50{ }^{\circ} \mathrm{C}, 100{ }^{\circ} \mathrm{C}, 150{ }^{\circ} \mathrm{C}$ and $200{ }^{\circ} \mathrm{C}$ 
Figure 4

Plot of unit cell volume at room temperature, $50{ }^{\circ} \mathrm{C}, 100{ }^{\circ} \mathrm{C}, 150{ }^{\circ} \mathrm{C}$ and $200{ }^{\circ} \mathrm{C}$

\section{Figure 5}

Schematic structures with thermal ellipsoids of $\mathrm{LiND}_{2}$ determined by neutron diffraction at room temperature, $50{ }^{\circ} \mathrm{C}, 100^{\circ} \mathrm{C}$ and $150{ }^{\circ} \mathrm{C}$, refined using GSAS/EXPGUI software

Table 1

Structural parameters of single crystal $\mathrm{LiND}_{2}$ at room temperature, $50{ }^{\circ} \mathrm{C}, 100{ }^{\circ} \mathrm{C}, 150{ }^{\circ} \mathrm{C}$ and $200{ }^{\circ} \mathrm{C}$

\begin{tabular}{|c|c|c|c|c|c|}
\hline Parameter & Room Tem & $.50^{\circ} \mathrm{C}$ & $100^{\circ} \mathrm{C}$ & $150{ }^{\circ} \mathrm{C}$ & $200{ }^{\circ} \mathrm{C}$ \\
\hline Structure & \multicolumn{5}{|l|}{ tetragonal } \\
\hline Space group & \multicolumn{5}{|l|}{$\mathrm{I}-4$} \\
\hline $\mathbf{a}$ & \begin{tabular}{|r}
5.0369 \\
$(17)$
\end{tabular} & $\begin{array}{r}5.0459 \\
(8)\end{array}$ & $\begin{array}{r}5.0533 \\
(8)\end{array}$ & \begin{tabular}{|r|r|}
5.0972 \\
$(10)$
\end{tabular} & \begin{tabular}{|r|r|}
5.1102 \\
$(10)$
\end{tabular} \\
\hline b & 5.0369 & 5.0459 & 5.0533 & 5.0972 & 5.1102 \\
\hline C & $\begin{array}{r}10.284 \\
(4)\end{array}$ & $\begin{array}{r}10.2818 \\
(18)\end{array}$ & $\begin{array}{r}10.2953 \\
(18)\end{array}$ & \begin{tabular}{|r}
10.3573 \\
$(22)$
\end{tabular} & $\begin{array}{r}10.3510 \\
(24)\end{array}$ \\
\hline Unit cell volume & $\begin{array}{r}260.91 \\
(16)\end{array}$ & $\begin{array}{r}261.79 \\
(7)\end{array}$ & \begin{tabular}{|r|}
262.90 \\
$(7)$
\end{tabular} & \begin{tabular}{|r|}
269.10 \\
$(9)$
\end{tabular} & \begin{tabular}{|r|}
270.31 \\
$(10)$ \\
\end{tabular} \\
\hline
\end{tabular}



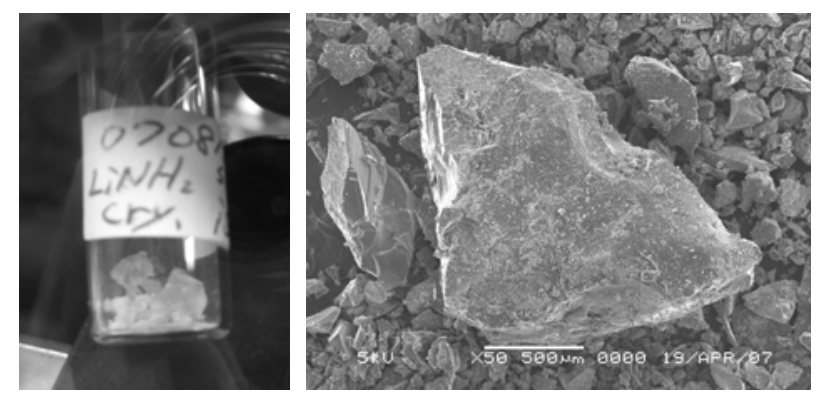

Figure 1 


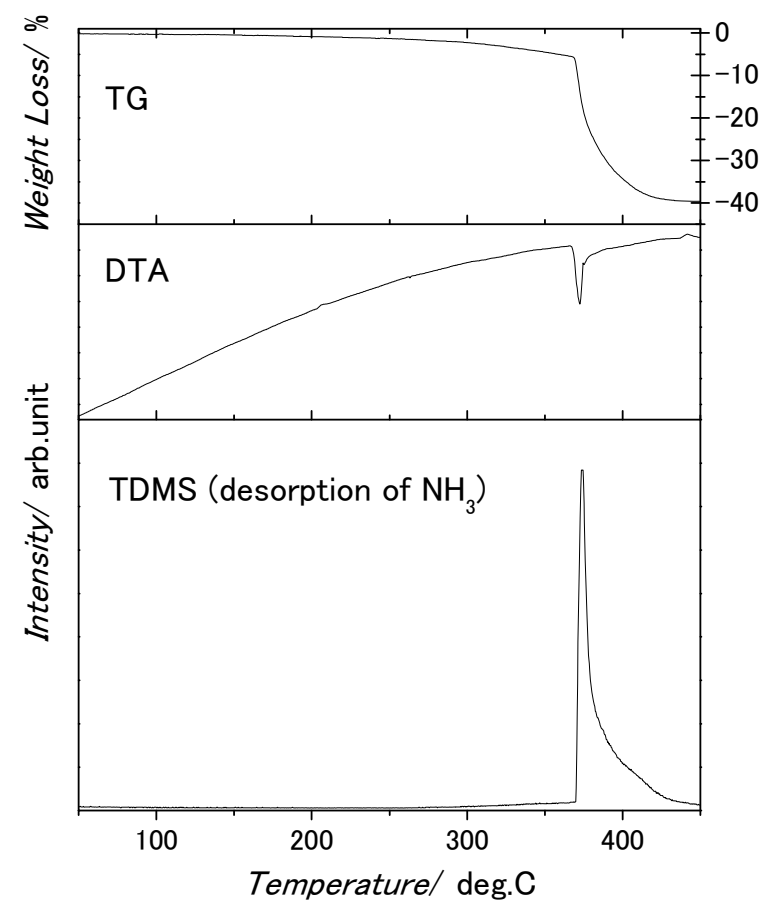

Figure 2 


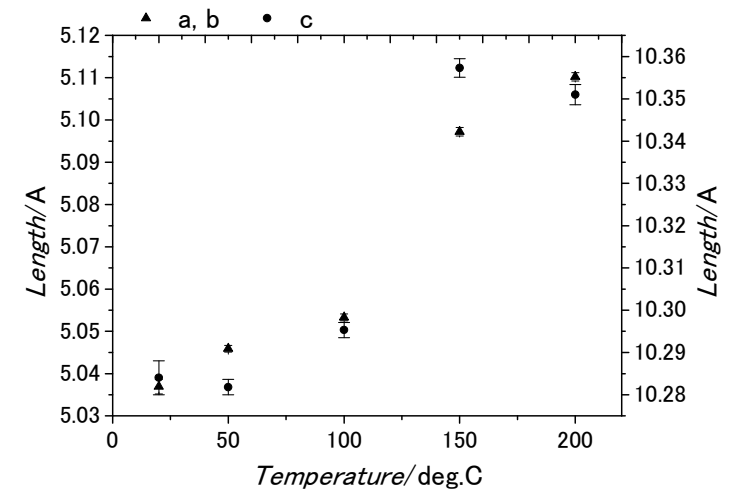

Figure 3 


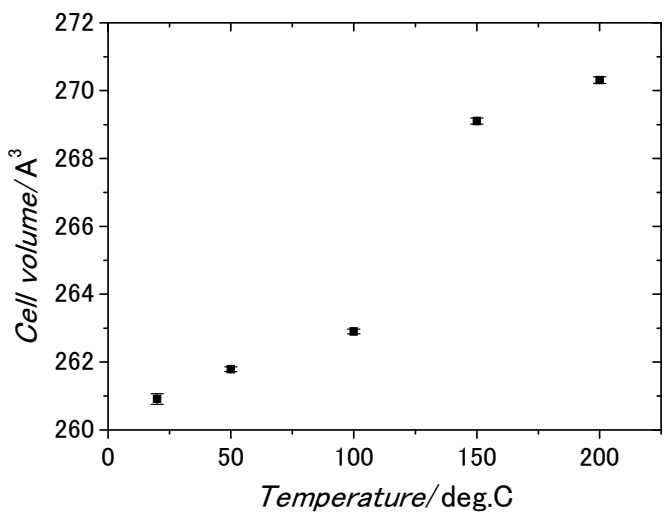

Figure 4 

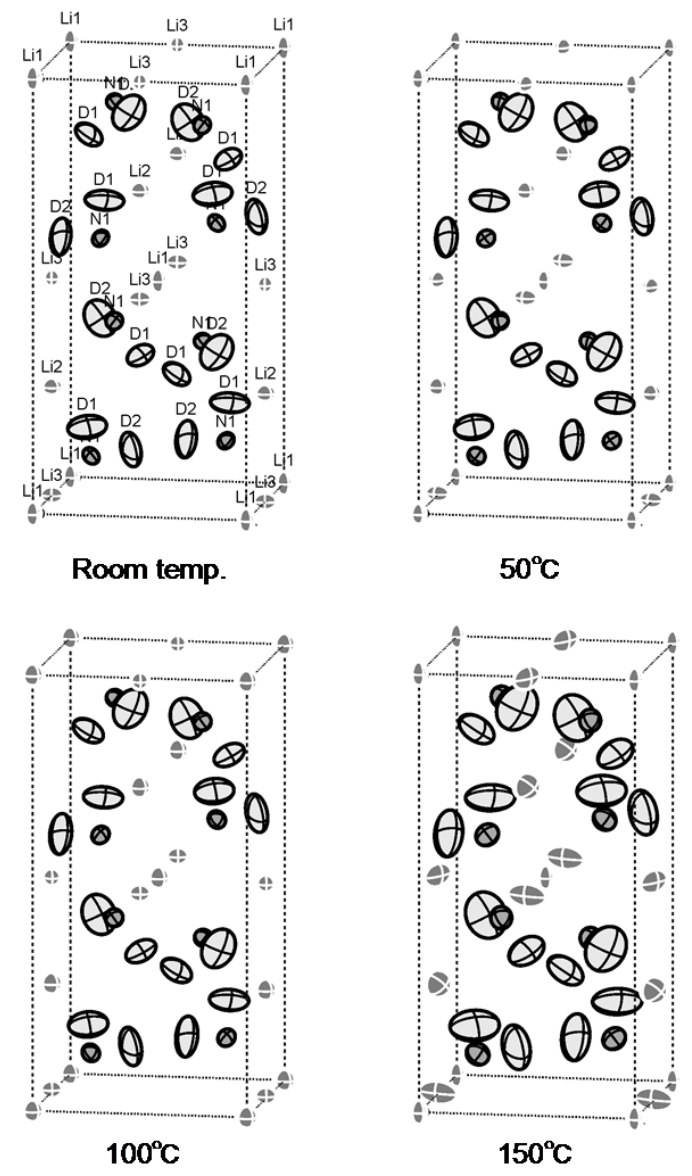

Figure 5 